\title{
O Discurso Parodístico: da Constituição à Comunicação
}

The Parodistic Speech: from Constitution to Communication

Rosemeri Passos Baltazar MACHADO*

Resumo: Este trabalho tem por objetivo refletir sobre o discurso parodístico, abordando os aspectos constituintes desse gênero e sua conceitualização. Sob a ótica da Análise do Discurso de orientação francesa, a proposta desse estudo é analisar o discurso parodístico segundo a perspectiva históricosocial e, a partir da concepção dialógica da linguagem, indentificar o que faz um discurso ser categorizado como parodístico. Em relação à língua e à sociedade, por exemplo, muito se pode discutir e compreender a respeito da paródia, principalmente no que tange ao irônico e humorístico, daí a importância de se ater não só nos aspectos explícitos, mas também nos implícitos, na imagem e na própria memória, como ocorre nas propagandas selecionadas para exemplificação. Conforme mencionado, foram selecionadas algumas propagandas que abordam o discurso parodístico com a finalidade de melhor compreender a constituição desse tipo de discurso bem como a dinâmica comunicativa que envolve a sociedade. Esta exemplificação se justifica, pois tanto a propaganda como a paródia estão repletas de estratégias manipulativas e de valores ideológicos. O componente dialógico é condição essencial para a construção dos sentidos, por meio dele é possível afirmar que a ruptura e continuidade constituem traços fundamentais para a definição e conceitualização do discurso parodístico. Palavras-chave: Discurso parodístico. Ruptura. Continuidade.

Abstract: This work aims to reflect on the parodistic speech addressing the constitutive aspects of gender and its conceptualization. From the perspective

* Doutorado em Estudos da Linguagem (2004) pela Universidade Estadual de Londrina. Atualmente é professora adjunto A, do Departamento de Letras Vernáculas e Clássicas, da Universidade Estadual de Londrina. Contato: rosemeri@sercomtel.com.br 
of French oriented Discourse Analysis, the purpose of this study is to analyze the parodistic speech according to the historical-social perspective and from the dialogic conception of language, identify what makes a speech to be categorized as parodistic. In relation to language and society, for example, much can be discussed and understood about parody, especially in regard to the humorous and ironic, hence the importance of focusing not only on the explicit aspects, but also implicit, in the image and memory itself, such as advertisements selected for exemplification. As mentioned, it was selected some advertisements that address the parodistic speech in order to better understand the constitution of this kind of discourse and the communicative dynamics that involves the society. This exemplification is justified, as both advertising and parody are full of manipulative strategies and ideological values. The dialogical component is essential for the construction of the senses, through it we can say that the rupture are continuity are essential features for the definition and conceptualization of parodistic speech.

Key-words: Parodistic speech. Rupture. Continuity.

\section{Introdução}

A fim de melhor compreender o processo discursivo da paródia e os aspectos envolvidos na sua constituição, esse artigo pretende, a partir do viés da Análise do Discurso de orientação francesa, apresentar uma reflexão a respeito, não só do conceito da própria enunciação parodística presente, muitas vezes, nos mais variados gêneros, como também comentar os aspectos constituintes desse tipo de discurso.

A proposta desse trabalho é pensar o discurso, segundo uma perspectiva histórico-social, numa relação que vai além de língua e fala, por isso parte-se da ideia de discurso, de acordo com uma visão semântica mais global dos efeitos de sentido e à luz da dialogicidade. A relação que um discurso mantém com o outro permite que ele seja visto como um sistema abstrato, no qual as trocas enunciativas são uma constante. É por meio dessas trocas que o sentido se constitui, se instaura e, nesse ponto, evidencia-se, com clareza, o componente dialógico como condição fundamental para a construção dos sentidos.

A paródia é, sem dúvida, uma modalidade discursiva que, desde a Antiguidade, ensina e diverte, ao mesmo tempo. Trata-se de uma perversão 
encarregada de desconstruir e construir sentidos. Segundo Shnaiderman, Likhatchóv e Pantchenko (apud CAVALIERE, 2009, p. 13):

Exteriormente, em sua camada superficial, o riso deforma intencionalmente o mundo, faz experimentos com ele, priva o mundo de explicações racionais e ligações de causa e efeito, etc. Mas, destruindo, o riso ao mesmo tempo constrói: ele cria o seu antimundo fantástico que traz em si determinada concepção do universo, determinada relação com a realidade ambiente. Esta relação do riso com a realidade é variável nas diferentes épocas e em diferentes povos.

É justamente pensando nesse processo, aqui chamado de ruptura e continuidade, que este trabalho propõe um estudo a respeito do próprio conceito de paródia, utilizando-se do discurso propagandístico ${ }^{1}$ como exemplo.

Primeiramente, faz-se um breve histórico a respeito do surgimento e da definição de paródia. Assim, são apontados alguns conceitos a respeito de paródia teorizados por diversos autores, dentre eles: Aristóteles, Genette e, como não poderia deixar de citar, Bakhtin, entre outros.

Logo após, comenta-se a respeito da materialidade discursiva da paródia, enfatizando o aspecto dialógico e a importância do sócio-histórico no processo de significação e comunicação nesse tipo de discurso. São observadas, também, as relações intertextuais/interdiscursivas e, para melhor compreensão a respeito do que se propõe esse trabalho, as materialidades discursivas desse tipo de gênero são apresentadas, tomando o discurso publicitário como exemplo.

Em seguida, são focados os aspectos da ruptura e da continuidade, fundamentais na definição do discurso parodístico, em peças publicitárias selecionadas de revistas - como Veja e Claudia - e da internet.

Após as exemplificações, a pesquisa segue para as considerações, enfatizando os mecanismos dos quais a paródia se utiliza na produção/

${ }^{1}$ Embora haja autores que tratem publicidade e propaganda como gêneros diferentes, no presente trabalho, tais termos serão empregados indistintamente, ou seja, tanto publicidade como propaganda ou discurso propagandístico referir-se-ão ao mesmo gênero. 
captação dos efeitos de sentido e, consequentemente, os aspectos que a definem enquanto um gênero discursivo.

\section{Paródia: um diálogo entre a oposição e a continuidade}

A paródia, definitivamente, não é um dos gêneros mais modernos. Conforme Sant'Anna (1995, p. 12), há quem afirme que a paródia surgiu no XVII, mas Aristóteles, na obra Poética, atribui a origem desse gênero, como arte, a Hegemon de Thaso (séc. V a.C.), pois, por meio do estilo épico, ele falava a respeito dos homens descrevendo-os como seres comuns, passíveis de erros, contrariando, de certa forma, o hábito da época. Mas há também alguns estudiosos que afirmam ter sido Hipponax de Éfeso (séc. VI a. C) o pai da paródia.

Como se pode notar, datar o surgimento, bem como dizer, com certeza, quem é o pai da paródia, não é tarefa das mais fáceis. Por uma questão de praticidade e de forma a atender aos objetivos propostos por esse trabalho, o mais indicado é partir do sentido dado ao termo. É comum associar paródia ao risível. As definições dadas por grande parte dos dicionaristas confirmam tal ideia. Biderman (1992, p. 695), por exemplo, define a paródia como "uma imitação cômica, satírica de uma obra literária (conto, romance, peça, poema, etc.)." Outra definição que também ressalta esse aspecto cômico da paródia é dada por Coelho (1996, p. 794-795) que conceitua a paródia "como as obras que decalcam outras (no entrecho, na estrutura formal, no vocabulário) com fim satírico e jocoso.” No entanto, mesmo diante de tais caracterizações de paródia, é importante destacar que é em meio a esse clima de humor que o discurso parodístico pode promover a reflexão e servir, inclusive, de representante ideológico.

Seguindo por esse caminho, pode-se pensar na paródia e no discurso por ela proferido como elementos artísticos caracterizadores da pós-modernidade. Por meio desse gênero, é possível demonstrar o quanto se sabe a respeito dos acontecimentos acerca do universo, denunciando o que, muitas vezes, está encoberto devido à contradição, insegurança ou até mesmo, devido à própria comodidade do espírito humano.

Phiddian (1997), em seu artigo intitulado Are parody and deconstruction secretly the same thing?, define a paródia pelo viés metafórico, descrevendo-a, primeiramente, como um jogo de diferenças, ou seja, como produções duplas e, ao mesmo tempo, distintas; e depois, como uma segunda escrita 
com a função de acrescentar algo, que visa a ser diferente, buscando sempre o discurso original no jogo da linguagem:

Paródia é o gênero parasita que pode se conectar a qualquer outro, completando-o perigosamente, vivendo a sua energia mimética, expressiva, ou retórica, e lembrando a ela e a nós que estamos diante de palavras ao invés de coisas, retórica em vez de ideias puras, linguagem, em vez de fenômenos. ${ }^{2}$ (PHIDDIAN, 1997, p. 689 tradução nossa).

Diante do exposto, até o momento, pode-se dizer que os termos "jogo" e "diferença” traduzem, não só o conceito, mas também a própria funcionalidade do gênero parodístico. Todavia, é importante atentar para o fato de que, mesmo diante desse jogo, a construção parodística deve respeitar certos limites, e a retomada (continuidade) é um desse limites, pois da mesma forma que há a quebra, deve haver também a retomada, caso isso não ocorra tornar-se-á muito difícil categorizar determinado gênero como paródia.

A paródia pode ser definida como uma construção bitextual com ênfase na oposição, assim, a repetição e a diferença devem ser vistas como processos embutidos nesse tipo de discurso. Hutcheon (1985, p. 16-56), seguindo por um viés, especificamente, textual, explica que a paródia nada mais é que um ir e vir intertextual, um misto de homenagem e ironia, uma superposição que incorpora o texto antigo ao novo e, portanto, há também um contextualismo.

Genett (1982, p. 11) descreve a paródia como um hipertex to e, assim como Hutcheon, também a define, ressaltando esse aspecto da duplicidade e da superposição. Segundo ele, a paródia transforma um determinado texto ao lado e ao mesmo tempo, contra o seu modelo (o texto parodiado). É necessário salientar que, no discurso parodístico, apesar de altamente polifônico, não há propriamente uma fusão de vozes, mas sim um jogo entre várias vozes. Nesse jogo polifônico, é possível captar essas vozes lado

2 Parody is the parasite genre that can attach to any other, supplementing it dangerous, living off its mimetic, expressive, or rhetorical energy, and reminding it and us that we are facing words rather than things, rhetoric rather than pure ideas, language rather than phenomena. 
a lado, traduzindo bem a ideia de contracanto proposta por Shipley (apud SANT'ANNA, 1995, p. 12), sugerindo que a paródia, inicialmente, referia-se apenas à música.

Para uma breve ilustração, focaliza-se o caso da estilização, em que as vozes se mesclam com a finalidade de contribuir com o sentido proposto anteriormente, isto é, o desvio feito no texto estilizante reforça ainda mais o sentido do texto estilizado.

A paródia é uma forma de apropriação, mas, ao contrário da estilização, procura o desvio ${ }^{3}$ (a oposição), rompendo de maneira perceptível e ao mesmo tempo sutil com o modelo seguido. Lembrando a concepção caranavalesca de Bakhtin, o discurso parodístico procura transgredir as leis, quebrar as convenções; entretanto, assim como o carnaval, só pode fazê-lo dentro de determinado período, ou seja, o dizer duplo é feito dentro dos limites estabelecidos pelas próprias condições de produção desse discurso.

Bakthin (1981, p. 168) faz uma importante observação enfatizando a duplicidade e a versatilidade do discurso parodístico:

Pode-se parodiar o estilo de um outro enquanto estilo; pode-se parodiar a maneira típico-social ou caracterológico-individual de o outro ver, pensar e falar. [...] podem-se parodiar apenas as formas superficiais do discurso como se podem parodiar até mesmo os princípios profundos do discurso do outro.

\section{A Materialidade Discursiva da Paródia}

A linguagem é o meio pelo qual a ideologia se manifesta, é por meio dela que o indivíduo se constitui enquanto sujeito. Orlandi (1993, p. 19) afirma que o sujeito não se utiliza da linguagem individualmente. Ao contrário, este processo constitui-se numa "apropriação social", processo pelo qual se estabelece a relação linguagem e sociedade. Seguindo o ponto de vista discursivo, a linguagem não está mais centrada exclusivamente na função

\footnotetext{
${ }^{3}$ De acordo com Paulino, Walty e Cury (1997, p. 37): “a paródia ainda que conservando sua caraterística de rompimento, pode também prestar uma homenagem ao texto ou ao seu autor", entretanto tal homenagem não deve exercer nenhum tipo de influência no conteúdo discordante e crítico que possui o discurso parodístico.
} 
referencial (passar informações), considerando as condições de produção e o aspecto sócio-histórico, tanto enunciador como enunciatário contribuem para o processo de significação, o que, por sua vez, leva a uma interação mais efetiva. Segundo Bakhtin (1990, p. 46),

Um enunciado isolado e concreto é dado num contexto cultural e semântico axiológico (científico, artístico, político, etc.)... ou no contexto de uma situação isolada da vida privada; apenas nesses contextos o enunciado isolado é vivo compreensível: ele é verdadeiro ou falso, belo ou disforme, sincero ou malicioso, franco, cínico, autoritário e assim por diante.

Ainda de acordo com Bakhtin (1990, p. 90), "a compreensão e a resposta [e neste ponto entra a participação do ouvinte, citada anteriormente] estão fundidas dialeticamente e reciprocamente condicionadas, sendo impossível uma sem a outra." Pode-se observar que é nesse percurso discursivo que mais se torna visível a noção dialógica da linguagem em que existe um "eu” que está ligado a um "outro" e ambos são detentores da consciência estabelecida a partir da compreensão. Daí a importância dos gêneros do discurso, ou melhor, do reconhecimento desses gêneros para o estabelecimento da comunicação. Ao se deparar com um discurso publicitário, por exemplo, o leitor/interlocutor, antes de iniciar a leitura de tal discurso, já consegue fazer a sua identificação e, inclusive, o reconhecimento de outros gêneros (como o parodístico) presentes nesse mesmo discurso. Segundo o autor, a capacidade discursiva deve-se ao fato de não haver a necessidade de se criar um novo gênero a cada evento comunicativo, afinal, os gêneros vão se transformando e se adequando às condições de produção e às ideologias.

Ainda em relação às condições de produção, deve-se atentar para o fato de que é a partir delas que os sentidos podem ser previstos e, dessa forma, constituir não só os sentidos do discurso como também regular a própria formação discursiva (FD) e, consequentemente, a formação ideológica (FI). Segundo Orlandi (2009, p. 18-19),

As formações discursivas são formações componentes das formações ideológicas e determinam o que pode e deve ser dito a partir de uma posição em uma conjuntura dada. As palavras mudam de sentido ao 
passarem de uma formação discursiva para outra, pois muda sua relação com a formação ideológica. [...] Além das intenções, contam, portanto, as convenções, havendo uma relação necessária do dizer com a ideologia.

Enfim, é a partir das vozes, representantes dos aspectos ideológicos vigentes, que os princípios reguladores do discurso vão sendo estabelecidos. Em meio a esse dialogismo, são vários os mecanismos (textuais e discursivos) que contribuem para emissão/compreensão dos efeitos de sentido. No que se refere à paródia, um dos principais aspectos a ser destacado é o da intertextualidade e, consequentemente, da interdiscursividade. Não há como definir paródia sem considerar o jogo intertextual. É essa relação estabelecida com outros já ditos que permite não só a identificação, mas também a própria memorização dos discursos.

Tal conclusão, além de direcionar esse trabalho, explica o mote que levou a estudar a presença de paródias em peças publicitárias, ou seja, é exatamente por essa propriedade de se fixar no pensamente do outro, de transmitir saberes por meio de já ditos que o discurso publicitário, por vezes, utiliza-se desse jogo intertextual e interdiscursivo. Dessa forma, além da divulgação do produto, há também outros aspectos que podem ser compartilhados entre os sujeitos participantes desse tipo de comunicação, isto é, no que se refere ao discurso publicitário, ao mesmo tempo em que há um locutor que - prevendo a existência de um alocutário, e mais ainda, de uma necessidade, numa determinada situação - diz algo (apresenta um certo produto), há um outro que busca por este dizer, um alocutário que espera que sua necessidade seja detectada e, consequentemente, atendida.

Se este dizer remeter a algo que seja de conhecimento de ambos os participantes da situação comunicativa em questão, ou seja, tanto a venda como a aquisição do produto (ou mesmo a mudança de comportamento apenas) tornam-se bem mais fáceis. Por isso compartilhar a mesma cultura e saber dos costumes entre os mais diversos universos somam aspectos relevantes a serem considerados pelo discurso publicitário. Esses processos podem, inclusive, servir de estratégias de divulgação e de domínio de mercado; afinal, são eles os responsáveis pelo sucesso tanto de divulgação/ venda como também de comunicação. Sob essa ótica, nunca é demais ressaltar o quão importante é o processo de leitura, interpretação/apreensão dos sentidos pelos sujeitos. Os sentidos não aparecem magicamente, é uma 
questão de memória, de resgate de outros saberes, de condição sócio-histórica, ou seja, os sujeitos vão constituindo e sendo constituídos a partir dessa relação entre língua, história e ideologia. Como afirma Orlandi (1996, p. 115):

Todo sujeito, a dizer, produz o que chamo um gesto mínimo de interpretação que é a inscrição de seu dizer no interdiscurso (no dizível) para que ele faça sentido. Aí trabalha um efeito ideológico elementar que está no fato de que todo discurso se liga a um discurso outro, por sua ausência necessária.

\subsection{Das relações intertextuais às interdiscursivas na paródia}

Os textos estão sempre em diálogo com outros textos. Essa dialogicidade constitui um dos aspectos que contribuem para a produção dos efeitos de sentido, ou seja, o reconhecimento desse fator, pelo leitor, facilita seu entendimento. Segundo Jenny (1979, p. 5), ao comentar a respeito da literatura, "fora da intertextualidade, a obra literária seria muito simplesmente incompreensível, tal como a palavra duma língua ainda desconhecida."

A intertextualidade está intrinsecamente ligada à textualidade, referese tanto ao momento da produção como o da recepção, isto é, ao conhecimento tanto por parte do produtor quanto do receptor na elaboração e compreensão do texto. Por isso não se pode deixar de pensar na questão da leitura, partindo do ponto de vista de que todo e qualquer texto é formado por outros textos, é um saber composto por outros saberes, a leitura acaba sendo o ponto chave no que diz respeito à intertextualidade.

Dessa forma, o texto é definido como um continuum que envolve transformação e intertextualidade, ou como afirma Kristeva (1974, p. 64), "um mosaico de citações, todo texto é absorção e transformação de um outro texto."

Seguindo por essa perspectiva da autora e buscando corresponder ao que se propõe o esse trabalho, é preciso refletir o texto (inscrição) em relação ao discurso (dinamização). O discurso significa o texto o qual, por sua vez, nunca é lido de uma única forma. É a partir das relações intertextuais que a interdiscursividade se apresenta sob a forma de diversas vozes e, consequentemente, de novos e variados sentidos. 
Tanto a prática intertextual quanto a interdiscursiva define uma espécie de horizonte de expectativa, sobre a qual o novo texto ou o novo discurso vem a se inscrever e a expressar o sentido. Todo texto, todo discurso, pela relação que estabelece com o texto/discurso geral, disseminam fragmentos de sentido já conhecido pelo leitor, desde a citação direta até a sua escritura mais elaborada. (GUIMARÃES, 2009, p. 139).

Na paródia, todas essas relações intertextuais e interdiscursivas são muito evidentes, o que facilita, de certa forma, não só a compreensão do próprio gênero parodístico como também daquele que o utiliza (no caso, o discurso publicitário). É claro que essa é uma questão que envolve muito mais do que apenas aspectos estruturais, há todo um conjunto a ser levado em consideração, afinal, o discurso (e, consequentemente a comunicação) é o ponto de partida para uma série de outros apontamentos, dentre eles, o ideológico. Nesse sentido, o mais conveniente seria considerar estudos do russo Bakhtin (2000, p. 282) que, com base na teoria dos gêneros discursivos, conseguiu demonstrar que o contexto comunicacional e sócio-histórico é necessário no processo de leitura e elaboração dos enunciados: "ignorar a natureza do enunciado e as particularidades do gênero que assinalam a variedade do discurso em qualquer área do estudo linguístico leva ao formalismo e à abstração, desvirtua a historicidade do estudo, enfraquece o vínculo existente entre a língua e a vida."

Em suma, o que se pretende destacar é a comunicação, ou melhor dizendo, a linguagem é descrita sempre dentro de uma determinada situação comunicativa, sob determinadas condições, visando sempre a troca. Por isso tornar-se-ia impossível pensar na propaganda, assim como qualquer outro tipo discursivo, sem levar em conta o público leitor/consumidor. Conforme estudos de Charaudeau (1996), tanto o nível situacional como o comunicacional e o discursivo devem ser considerados em todo ato de linguagem. É a partir do ato de linguagem que o chamado contrato de comunicação entre o sujeito comunicante e o sujeito interpretante é efetivado internamente (nível textual) e externamente entre o enunciador e enunciatário (nível discursivo). Isto quer dizer que existe um "eu" e um "tu" que se comunicam e interagem numa encenação (mise en scène), e ambos são, evidentemente, influenciados, entrecortados, por aspectos ideológicos. 
Por isso, no que corresponde ao discurso publicitário, apesar dos efeitos de produção, cada vez mais elaborados e modernos, tecnologicamente falando, o foco é a interação, ou seja, tudo que é produzido nesse tipo de discurso é feito para atingir o interlocutor, para prender a sua atenção de tal modo que sua ação é, na realidade, um resultado, na maioria das vezes, previamente esperado. Entretanto, não se pretende, com isso, dizer que há aí um sujeito que, num papel de passividade, seja apenas levado a uma ação. Pelo contrário esse sujeito interlocutor também tem memória e, consequentemente, participa da provocação dos sentidos. Segundo Maingueneau (1997, p. 49),

... o interlocutor não é apenas um indivíduo para quem se propõem idéias que correspondem aproximadamente a seus interesses; é também alguém que tem acesso ao dito através de uma maneira de dizer que está enraizada em uma maneira de ser, o imaginário de um vivido. Note-se, aliás, que esta concepção da eficácia discursiva é constantemente integrada pelos tex tos publicitários, que mostram de forma paroxística aquilo que provavelmente constitui a tentativa de toda formação discursiva: convencer consiste em atestar o que é dito na própria enunciação, permitindo a identificação com uma certa determinação do corpo.

\subsection{Ruptura e continuidade: novas leituras, novos sentidos}

Conforme já comentado, tudo é uma questão de estratégia, de manipulação a fim de conquistar o público, desde o emprego da paródia, no gênero publicitário em questão e de todos os aspectos nela envolvidos, até o direcionamento da ação do sujeito leitor/consumidor.

No que se refere às peças publicitárias, sem dúvida, a utilização do discurso parodístico só tende a contribuir, já que a paródia é gênero facilmente memorizável, pois muito do que está nela contido já é conhecido e, na maioria das vezes, de domínio popular. Dessa forma, ela ajuda a fixar o nome do produto por meio do que já está na memória do interlocutor.

O discurso parodístico mobiliza o que é parte da formação do indivíduo, ou seja, por meio desse discurso manifesta-se a cultura, os costumes e, também, a ideologia de um povo. Ao analisar a presença da paródia nas peças publicitárias, faz-se um trabalho no qual a arte está presente duplamente. 
Lembrando Sant'anna (1995, p. 7), “... a freqüência com que aparecem textos parodísitcos testemunha que a arte comtemporânea se compraz num exercício de linguagem no qual ela se dobra sobre si mesma num jogo de espelhos."

Atualmente, com o avanço tecnológico e a era digital, as peças publicitárias estão cada vez mais elaboradas e atrativas aos olhos do leitor. Nesse sentido, assim como a paródia, muitas propagandas podem, também, ser consideradas arte. Ambos os processos artísticos (paródia e propaganda) visam à busca de novas leituras, novos sentidos, novas formas de conhecer e de ser conhecido. Ao se deparar com uma peça publicitária que utiliza determinado discurso parodístico, não só o produto passa a ser conhecido, mas também a própria ideologia, tanto do público, como da sociedade, do veículo de divulgação, enfim, dos sujeitos envolvidos na comunicação, bem como todo o conteúdo sócio-histórico.

$\mathrm{Na}$ propaganda do Jornal do Brasil (Revista Claudia, de julho de 2001), verifica-se o jogo parodístico com a expressão clichê "Doa a quem doer".

\section{Falamos a verdade doa a quem doer. \\ E damos um DVD assine a quem assinar.}

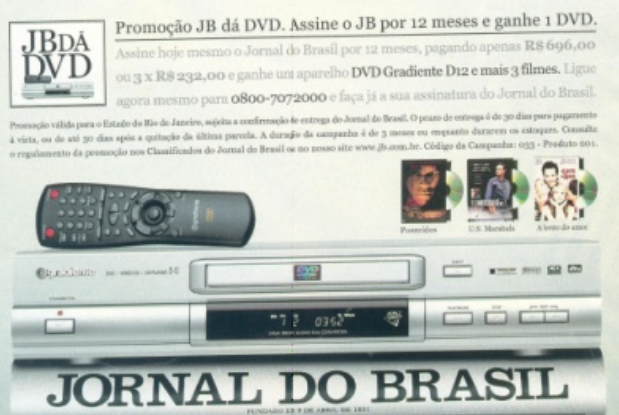


Nessa peça, além do emprego da expressão popular "Doa a quem doer" (intertextualidade explícita), o discurso propagandístico é plenamente reconhecido por meio da continuidade estabelecida com o enunciado “... assine a quem assinar" (intertextualidade implícita). Ao inscrever a expressão "Falamos a verdade doa a quem doer.", o interlocutor aciona seu conhecimento e, por meio do resgate feito à memória, consegue identificar o texto fonte e, a partir da continuidade dada a esse enunciado - "E damos um DVD assine a quem assinar" - outro sentido é captado e, consequentemente, mais um saber é agregado a outros já armazenados. Charaudeau (2007, p. 43-44), ao comentar a respeito do saber apreendido por meio do conhecimento, afirma que esse tipo de saber se constrói a partir das representações do mundo, ou seja,

Trata-se, para o homem, de tentar tornar o mundo inteligível, colocando marcas no continuum de sua materialidade, determinando fronteiras que permitam distinguir o que é semelhante do que é diferente, estabelecendo relações de contigüidade e de substituição entre os elementos depreendidos para estabelecer hierarquias, conjuntos e subconjuntos, isto é, construir taxionomias.

A paródia manifesta-se de várias maneiras, por isso pode haver algumas incertezas quanto à sua categorização, principalmente, quando a ênfase é no nível da imagem. Na peça comentada anteriormente, o foco estava na linguagem verbal, por isso a facilidade de perceber a presença do discurso parodístico.

Na peça a seguir, referente a calçados femininos, publicada na Revista Desfile, de abril de 1992, o jogo proposto por meio da presença da continuidade do discurso é bem mais difícil de ser captada, pois o texto fonte apresentado possui seu sentido total calcado no código verbal, em um lado da página, e a continuidade desse mesmo discurso ocorre a partir de uma imagem do calçado na página seguinte. 


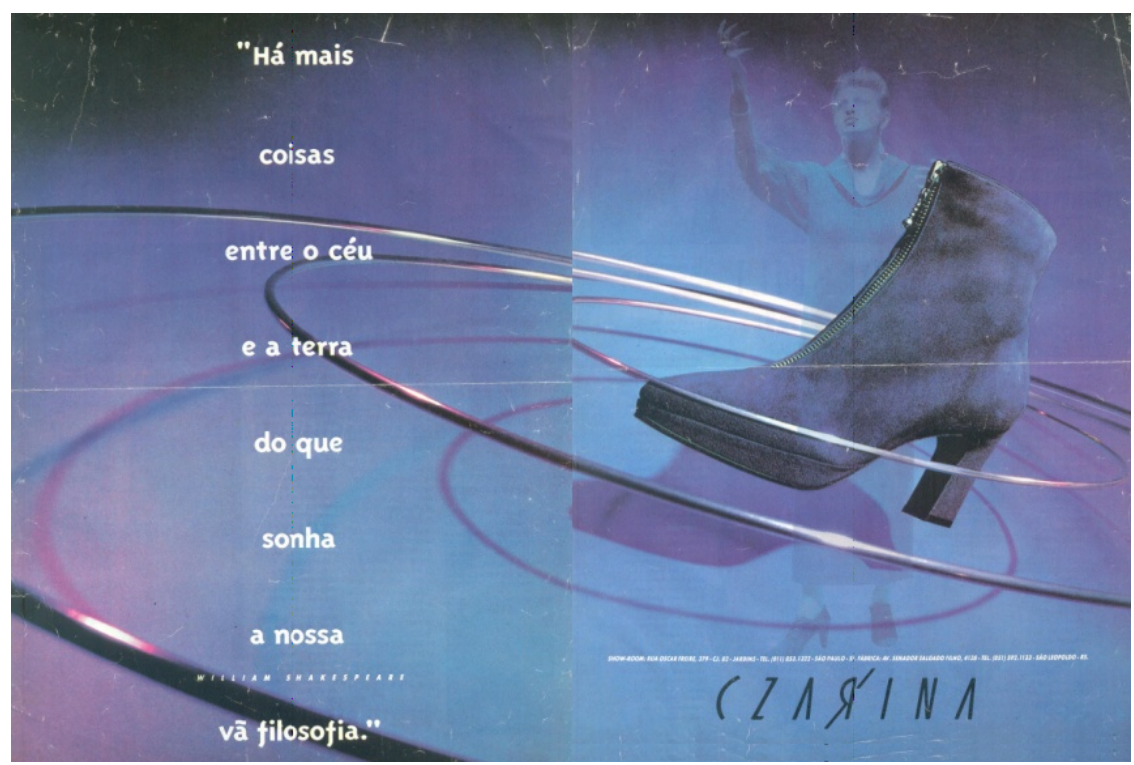

Ao se deparar com o texto-base, poder-se-ia cogitar em um caso de referência apenas, ou seja, a peça publicitária em questão utiliza-se da citação de um clássico, no entanto, sob a ótica da textualidade, trata-s e de intertextualidade explícita, com o propósito de funcionar como um argumento por autoridade (tom reforçado pela presença das aspas, pois é a partir delas que se verifica a heterogeneidade mostrada e marcada).

Todavia, deve-se entender que o discurso propagandístico só termina com a apresentação do conteúdo da página seguinte: a imagem do calçado. Assim sendo, o que se apreende é, de fato, a continuação do pensamento exposto anteriormente: Uma das coisas que pode existir entre o céu e a terra é a marca "CZA Я ÍNA" de calçados femininos. Há de se atentar, também, para o fato de tal intertextualidade revelar a identidade, não só do público-alvo, mas também da própria revista na qual está veiculada. Trata-se de uma revista, cujo próprio nome ("Desfile”) já faz referência à moda. A utilização de Shakespeare na peça proporciona um tom de elegância que, por sua vez, fornece maior credibilidade ao produto e, certamente, visa a um público detentor de certo poder aquisitivo e de um nível cultural, no mínimo, mediano. No entanto, tais exigências, por assim dizer, não torna tal público tão restrito quanto se possa imaginar, afinal, o acesso à escola, ao 
conhecimento formal, na época em que foi produzida (1992), já era maior em relação às décadas anteriores. Nesse sentido, a citação não é de todo estranha, por isso associá-la à marca é muito mais fácil e rápido.

Maingueneau (2011), ao comentar a respeito das competências que influenciam, diretamente, no conhecimento do discurso, explica que todo discurso possui regras, "leis" ("competência genérica”) às quais são essenciais no processo de leitura, interpretação e apreensão dos sentidos dos enunciados (“competência comunicativa"). O autor ainda ressalta que não há uma ordem sequencial para que estas competências ocorram ou possam ser verificadas, elas interagem para que, de fato, a interpretação seja possível.

O domínio da competência comunicativa, evidentemente, não é o suficiente para se participar de uma atividade verbal. Outras instâncias devem ser mobilizadas para produzir e interpretar um enunciado. É preciso, naturalmente, uma competência lingüística, o domínio da língua em questão. É preciso, além disso, dispor de um número considerável de conhecimento sobre o mundo, uma competência enciclopédica. (MAINGUENEAU, 2011, p. 41 - grifos nossos).

Em 2005, a empresa O Boticário lançou a campanha publicitária "Contos de Fadas", pela agência AlmapBBDO. Nas peças divulgadas na Revista Veja (primeira e segunda peça de 27/07/2005 e 03/08/2005, respectivamente) e na Revista Claudia (terceira peça de julho de 2005), o discurso parodístico é estabelecido com as histórias infantis, uma delas, inclusive, mantém a mesma estrutura inicial do gênero-base história infantil: "Era uma vez...". Tanto o conteúdo verbal escrito como o não verbal estabelecem, facilmente, a relação intertextual e interdiscursiva (remetendo à ideia da sensualidade e do poder de conquista feminino: “... coloca o lobo mau na coleira.” / “... Mas vários morenos de 1.80m.”). 


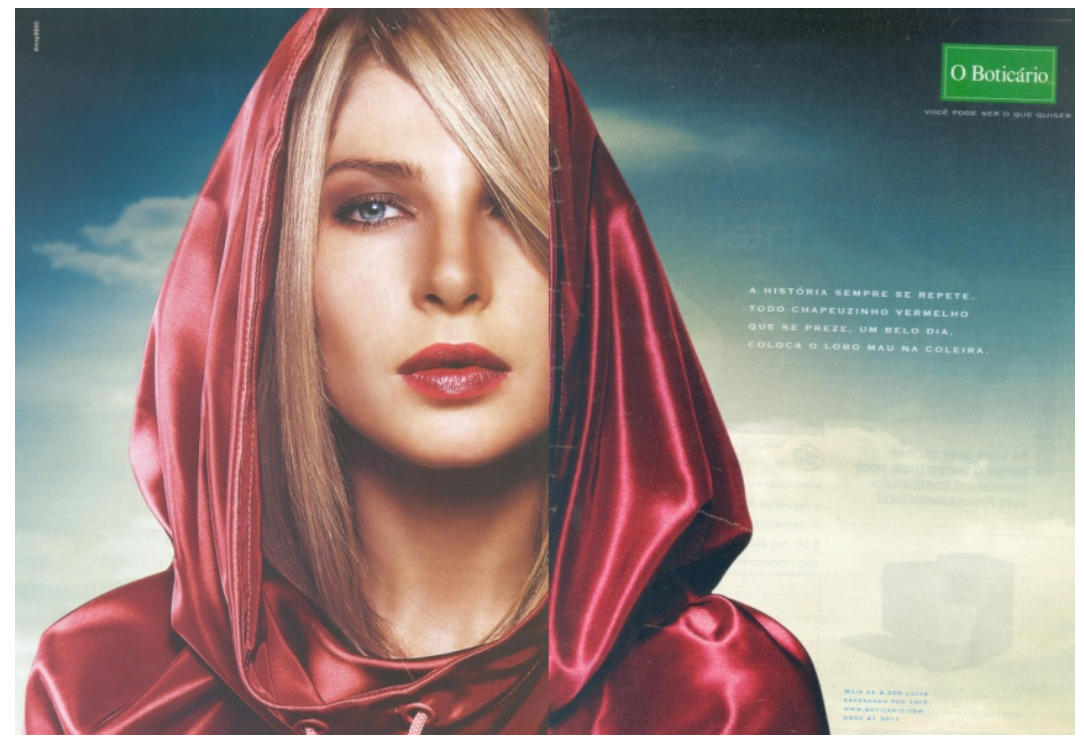

"A HISTÓRIA SEMPRE SE REPETE. TODO CHAPEUZINHO VERMELHO QUE SE PREZE, UM BELO DIA, COLOCA O LOBO MAU NA COLEIRA."

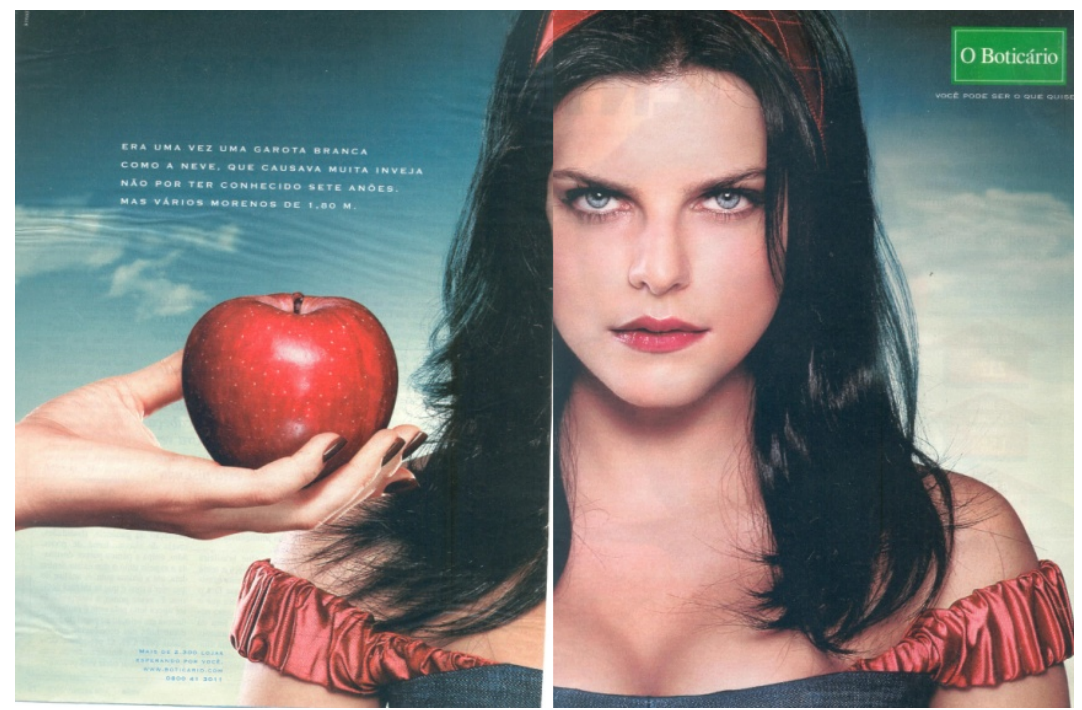

"ERA UMA VEZ UMA GAROTA BRANCA COMO A NEVE, QUE CAUSAVA MUITA INVEJA NÃO POR TER CONHECIDO SETE ANÕES. MAS VÁRIOS MORENOS DE 1,80M." 


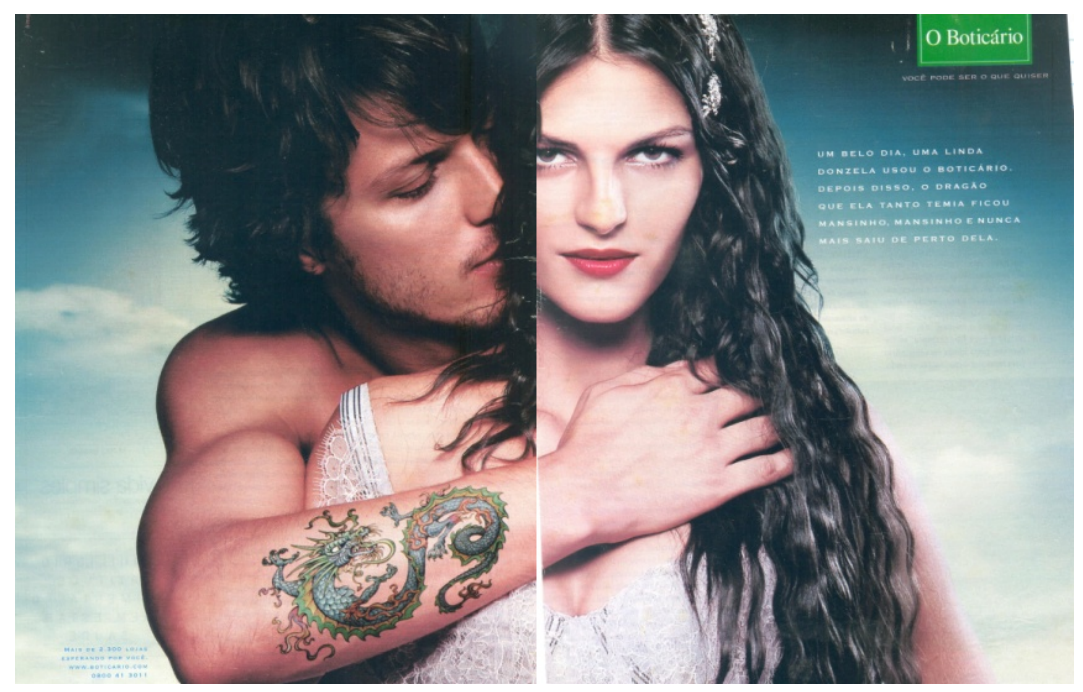

"UM BELO DIA, UMA LINDA DONZELA USOU O BOTICÁRIO. DEPOIS DISSO, O DRAGÃO QUE ELA TANTO TEMIA FICOU MANSINHO, MANSINHO E NUNCA MAIS SAIU DE PERTO DELA."

Voltando à ideia do domínio popular ou do senso comum, comentado anteriormente, essas peças da empresa de produtos de beleza optaram por utilizar discursos parodísticos de histórias infantis, o que facilitou, sobremaneria, a captação dos sentidos por parte dos interlocutores. Nesse aspecto, ressalta-se, mais uma vez, a importância do reconhecimento da duplicidade que, de acordo com os comentários de Kothe (1980, p. 101), é essencial para o conceito de paródia:

... sob o nível de superfície precisa estar organizado e precisa ser reconhecido um outro texto. Este texto está implicitamente explícito e explicitamente implícito. A eficácia da paródia (como da piada: não por acaso a paródia tende a ser cômica) decorre da tensão que se estabelece entre os dois níveis do texto, ou melhor, no desnível entre os dois textos: não por eles 'em si mesmo' como textos, mas devido aos grandes valores ideológicos que eles mobilizam. 
Em meio a essa duplicidade, o jogo de sedução e persuasão presente nas três peças denotam um misto de humor e leveza, pois a beleza das modelos, associada à inocência das princesas das histórias infantis parodiadas e à polissemia do conteúdo verbal, acaba por revelar a polifonia irônica desses discursos propagandísticos.

Conforme comentado, a paródia vai além da chamada ruptura e continuidade, ela é, também, renovação de sentido. No que se refere às peças publicitárias, tal renovação ocorre de forma ainda mais ampla, isto é, além de o discurso parodístico ser outro, o momento sócio-histórico, os objetivos e o próprio veículo também são diferentes. Pode-se dizer que outra transformação está no uso desse gênero paródístico, ou seja, toma-se um gênero (até então restrito ao universo da literatura clássica), transforma-o/deforma-o e o coloca dentro de uma outra esfera, a da publicidade.

Apenas no sentido de reforçar o aspecto da intercomunicação entre os gêneros, a seleção a seguir, cuja base (texto-fonte) está nos títulos de filmes, há uma espécie de configuração híbrida que ocorre em meio à noção de ruptura e continuidade estabelecida pelo discurso parodístico, dentro do discurso publicitário, com formulações de propósitos, no que tange ao textobase, obviamente, diferentes.

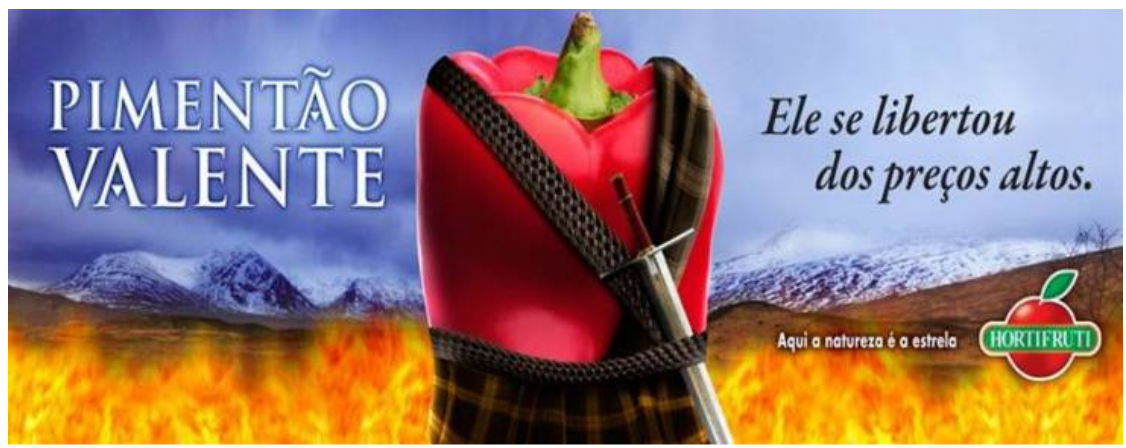



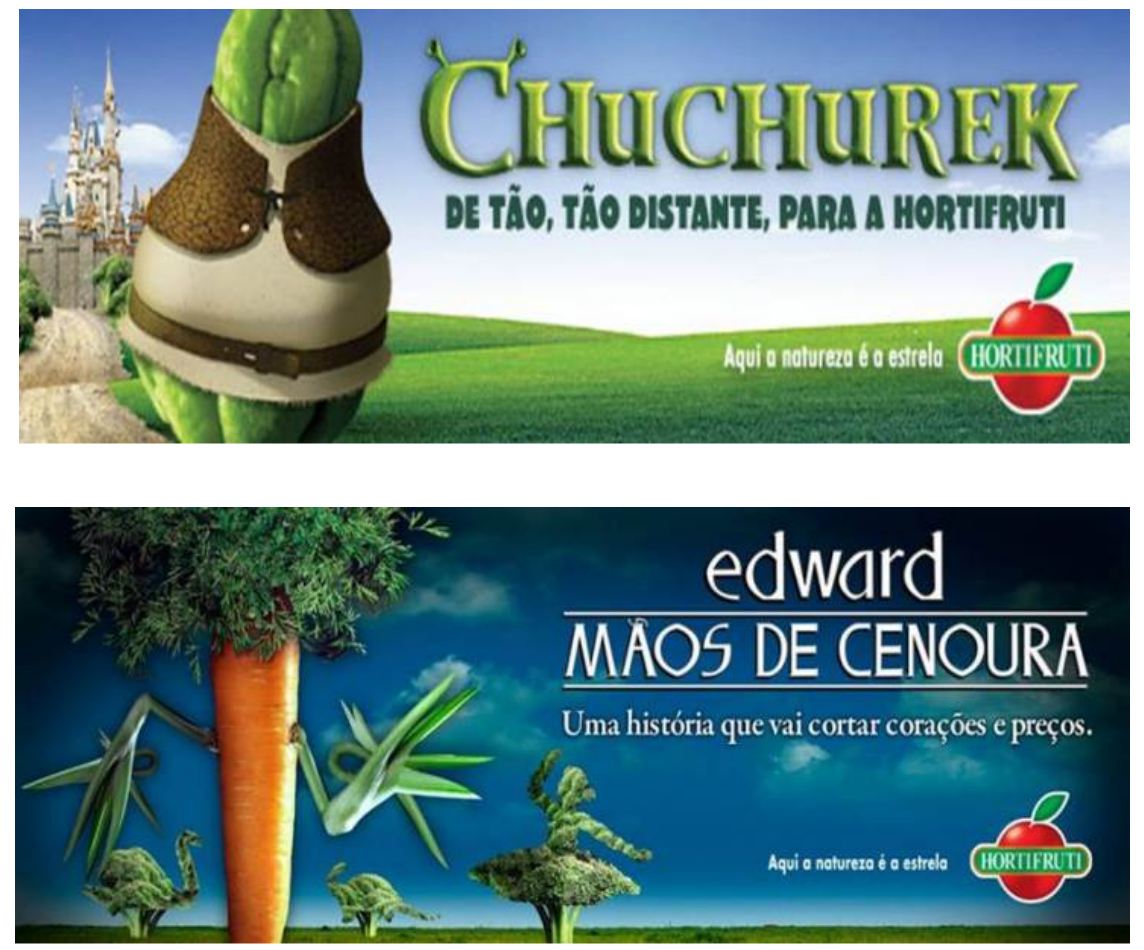

Mais uma vez, o sujeito leitor/interlocutor faz um exercício de reconhecimento de um determinado gênero (filme), dentro da propaganda. Nessa série de peças publicitárias da Hortifruti, retiradas da internet ${ }^{4}$, além de divulgar a marca, o discurso parodístico segue com o intuito de enfatizar o humor, principalmente devido às imagens que, iconicamente, já remetem a um já dito e, consequentemente, facilitam a comunicação; reforçando, assim, a ideia de que os discursos nada mais são que dizeres já ditos, que produções baseadas no Outro (Outro que pode ser para quem se fala e, ao mesmo tempo, por quem se fala). Segundo Authier-Revuz (2004, p. 69 grifos do autor),

${ }^{4}$ Disponível em: <http://www.hortifruti.com.br/campanhas/campanhashortifruti.http $>$. 
Todo discurso se mostra constitutivamente atravessado pelos 'outros discursos’ e pelo ‘discurso do Outro’. O outro não é um objeto (exterior, do qual se fala), mas uma condição (constitutiva, para que se fale) do discurso de um sujeito falante que não é fonte-primeira desse discurso.

Da mesma forma, ocorre com a peça publicitária da JONTEX, na qual o sentido é transmitido e captado/interpretado, por meio da relação que o interlocutor, ao acionar a sua memória, consegue estabelecer com a imagem da estrada, imitando a barriga de uma mulher grávida (quebra de expectativa) e a expressão "evite acidentes" (retomada do sentido). Tal relação, ao mesmo tempo em que revela sentido polissêmico (o termo "acidente" relacionado às fatalidades de trânsito ou à gravidez não planejada), também reforça o aspecto cômico levando ao riso.

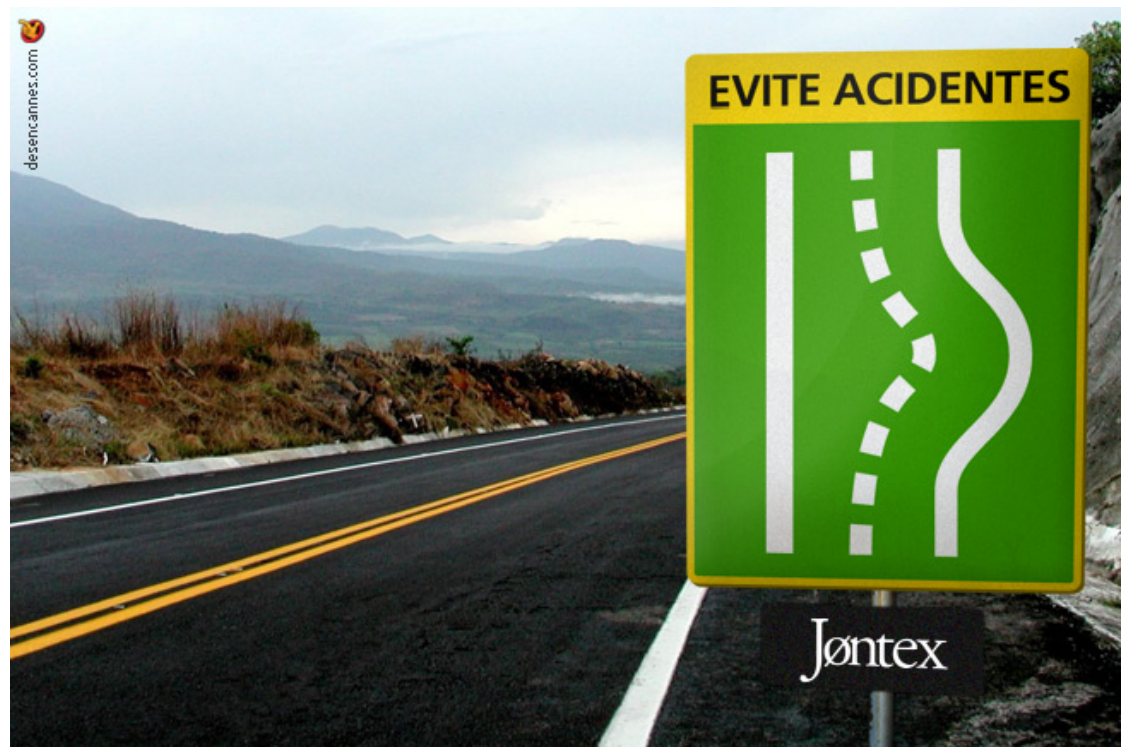

Em relação ao cômico, Piviani (1983, p.15) comenta que é por meio do riso que os sentidos também são desvelados:

De qualquer forma, o riso é uma prerrogativa do homem: ele é o sujeito e o objeto do próprio riso. O cômico revela tanto a verdadeira 
como a falsa sabedoria humana. Rir é próprio da finitude do homem. Há um certo orgulho em quem ri, como também uma certa inocência. Por outro lado o cômico desvela o oculto na evidência e a poesia na indiferença.

Como se pode notar, a utilização do discurso parodístico publicitário, além de facilitar a comunicação, fazer a marca fixar na mente do sujeito interlocutor, aproxima os sujeitos da comunicação em questão, não só por meio de associações rápidas propiciadas ao sujeito interlocutor (possível consumidor), mas também pelo aspecto cômico fundador desse tipo de discurso.

Na peça publicitária da revista Veja, edição 120, de 23 de dezembro de 1970, além do discurso parodístico referente aos Dez Mandamentos (texto-fonte), o humor e a ironia também são captados, principalmente pela subversão instaurada por meio dos provérbios. Esses são os atravessamentos, as vozes entrecortadas que todo discurso carrega em seu processo enunciativo. Como afirma Authier-Revuz (2004, p. 69 - grifos do autor), em seus estudos referentes às comunicações linguageiras ou atividades linguísticas, "Todo discurso se mostra constitutivamente atravessado pelos 'outros discursos' e pelo 'discurso do Outro'. O outro não é um objeto (exterior, do qual se fala), mas uma condição (constitutiva, para que se fale) do discurso de um sujeito falante que não é fonte-primeira desse discurso."

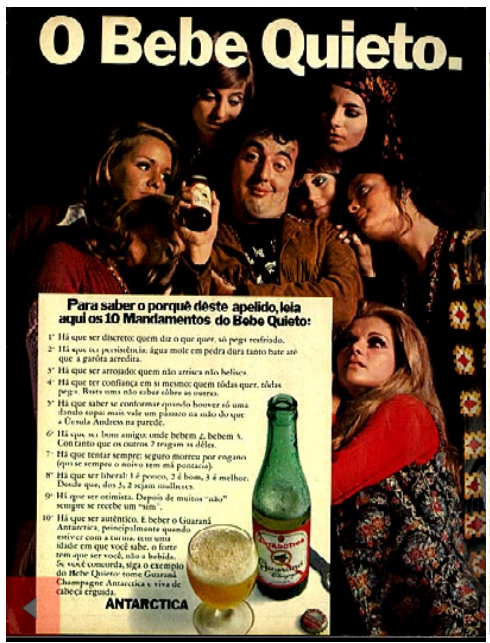

$1^{\circ}$ Hă que ser discreto: quem diz o que quer, só pega resfriado. 2. Há que ter persistência: água mole em pedra dura tanto bate até que a garôta acredita.

3. Há que ser arrojado: quem não arrisca não belisca

$4^{\circ}$ Há que ter confiança em si mesmo: quem tôdas quer, tôdas pega. Basta uma não saber sôbrc as outras.

5. Há que saber se conformar quando houver só uma dando sopa: mais vale um pássaro na mão do que a Úrsula Andress na parede.

6. Há que ser bom amigo: onde bebem 2, bebem 3 . Contanto que os outros 2 tragam as dêles.

$7^{\circ}$ Há que tentar sempre: seguro morreu por engano (quase sempre o noivo tem má pontaria)

$8^{\circ}$ Há que ser liberal: 1 ć pouco, 2 é bom, 3 é melhor. Desde que, dos 3, 2 sejam mulheres.

9 "Há que ser otimista. Depois de muitos "nào" sempre se recebe um "sim".

10. Há que ser autêntico. E beber o Guaraná Antarctica, principalmente quando estiver com a turma: tem uma idade em que você sabe, o forte tem que ser você, ñ̃o a bebida. Se você concorda, siga o exemplo do Bebe Quieto: tome Guaraná Champagne Antarctica e viva de cabeça erguida.

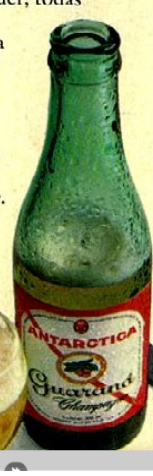


Ao mencionar o primeiro enunciado, no formato de um mandamento bíblico, percebe-se, claramente, o aproveitamento de um já dado/conhecido para significar outro sentido: “... quem diz o que quer, só pega resfriado”, "... água mole em pedra dura, tanto bate até que a garôta acredita", “... quem não arrisca, não belisca.”, “... quem todas quer, todas pega. Basta uma não saber sobre as outras." “...mais vale um pássaro na mão, do que a Úrsula Andress na parede.” A partir dos provérbios parodísticos, fica evidente a imagem invertida que o discurso propicia e, consequentemente, a ambiguidade do gênero. Como afirma Monegal (1980, p. 21), a luta contra o original e a transformação são constantes nesse jogo:

A paródia é a conscientização do ultrapassado, no vigente, ou melhor, é o lugar onde se manifesta a dúvida sobre os valores tradicionais. $\mathrm{O}$ olhar profundo que a caracteriza aponta para a possibilidade de transformação do presente, seja pela crítica à sociedade atual, às tradições, seja pela abertura que permite a passagem a novas possibilidades de ser e de pensar. Ela nos apresenta uma terceira realidade, que não é nem a do contexto, nem a do texto literário original.

No que se refere aos provérbios parodísticos, há nos discursos por eles proferidos, o que Maingueneau (2011, p. 174) classificou como "subversão do gênero do discurso", ou seja, há uma subversão do gênero proverbial, um provérbio que contesta "o próprio gênero do provérbio". A cada dito conhecido é acrescentado um dado novo de forma irônica ${ }^{5}$ e, neste caso, ridicularizadora, pois coloca em situação de desvalorização a autoridade da sabedoria popular", gerando, por sua vez, num tom de humor, uma ressignificação. Assim como as peças publicitárias do calçado "CZA ЯÍNA" e do Jornal do Brasil, a propaganda do Guaraná Antártica, também, se utiliza da subversão, da quebra e da continuidade próprios do

${ }^{5}$ Partindo das ideias de Maingueneau (2011,p. 174-175), há diferenças entre o provérbio e a ironia; contudo, qualquer enunciação pode ser irônica, "inclusive a enunciação de provérbio". No caso do provérbio parodístico, por exemplo, a ironia constitui um aspecto quase que inequívoco, afinal, assim como a ironia ("se mantém na fronteira entre o que é assumido e o que é rejeitado"), o provérbio parodístico também se revela ambíguo. 
discurso parodístico como formas de argumentação e de conquista de público.

\section{Considerações Finais}

Esse trabalho permitiu mostrar, primeiramente, o quanto é impossível tratar da questão discursiva como algo fechado, único e monológico. Em toda composição, analisada discursivamente, há sempre o atravessamento de outras vozes e, consequentemente, a produção/captação de outros sentidos. Todo e qualquer discurso é, na realidade, um dito composto de outros já ditos. Transmite-se um saber a partir de outros saberes.

No que tange à paródia, especificamente, ela busca a ressignificação (no sentido de significar outro diferente) a partir daquilo que é do domínio comum, ou seja, é um gênero que visa à ruptura e à continuidade. A ruptura refere-se ao momento em que se faz a identificação do texto fonte dentro do texto em questão. A continuidade é detectada a partir do segundo texto (de outro dizer), isto é, são captados novos sentidos e outros saberes a partir do já dito/sabido. Relembrando a perspectiva de estudo da Análise do Discurso, nenhum discurso é uno, original e, muito menos, solitário. O discurso parodístico destaca o aspecto do domínio comum, ou seja, referese ao saber que deve ser partilhado pelos indivíduos implicados na comunicação. O jogo parodístico instala a reapropriação do que foi dito em outro dizer, agora irônico, jocoso e criativo.

Com relação à intergenericidade detectada no presente estudo, ponto chave do discurso parodístico, deve-se dizer que foi empregada com o intuito de, primeiramente, chamar a atenção do público, uma vez que se trata de publicidade, e depois, devido ao uso da paródia, convencer o interlocutor mais facilmente e por meio do humor. A sobreposição textual verificada, nesse caso, serviu como aliada no processo de elaboração, transmissão e captação dos efeitos de sentido. $O$ velho foi, não somente, recriado para reforçar a diferença, mas também para enfatizar a mudança e mostrar as possibilidades de uso/divulgação.

\section{Referências}

ARAGÃO, M. L. P. de. A paródia em 'A força do destino'. Tempo Brasileiro, n. 62, p. 18-28, jul./set. 1980. 
AUTHIER-REVUZ, J. Heterogeneidade(s) enunciativa(s). Cadernos de Estudos Linguísticos, v. 19, n. 1, p. 25-42, 1990.

AUTHIER-REVUZ, J. Entre a transparência e a opacidade. Um estudo enunciativo do sentido. Tradução de Eurico Saldanha de Lemos, Leci Borges Barbisan (revisão) e Valdir do Nascimento Flores (revisão). Porto Alegre: EDIPUCRS, 2004.

BAKHTIN, M. M. Problemas da poética de Dostoiévski. Tradução de Paulo Bezerra. Rio de Janeiro: Forense-Universitária, 1981.

BAKHTIN, M. M. Questões de literatura e estética: a teoria do romance. 2. ed. Tradução de Aurora Fornoni Bernardini. São Paulo: HUCITEC, 1990.

BAKHTIN, M. M. Estética da criação verbal. 3. ed. Tradução de Maria Ermantina Galvão. Revisão da tradução de Marina Appenzeller. São Paulo: Martins Fontes, 2000.

BIDERMAN, M. T. Dicionário contemporâneo de Português. Petrópolis: Vozes, 1992.

CAVALIERE, A. Teatro russo: percurso para um estudo da paródia e do grotesco. São Paulo: Humanitas, 2009.

CHARAUDEAU, P. Discurso das mídias. Tradução de Ângela S. M. Corrêa. São Paulo: Contexto, 2007.

CHARAUDEAU, P. Para uma nova análise do discurso. In: CARNEIRO, A. D. O discurso da mídia. Rio de Janeiro: Oficina do Autor, 1996.

COELHO, J. do P. Dicionário de literatura portuguesa, brasileira, galega e estilística literária. v. 4. 3. ed. Porto: Figueirinhas Porto, 1984.

GENETTE, G. Palimpsestes: la litérature au second degré. França: Edtions du Seuil, 1982.

GUIMARÃES, E. Texto, discurso e ensino. São Paulo: Contexto, 2009.

HUTCHEON, L. Uma teoria da paródia: ensinamentos das formas de Arte do século XX. Tradução de Teresa Louro Pérez. Lisboa: Edições 70, 1985. 
JENNY, L. A estratégia da forma. In Poétique - Revista de Teoria e Análises Literárias, n. 27, p. 5-49, 1979.

KOTHE, F. R. Paródia e Cia. Tempo Brasileiro, n. 62, p. 97-113, jul./set. 1980.

KRISTEVA, J. Introdução à Semanálise. Tradução de Lúcia Delena Franca Ferraz. São Paulo: Perspectiva, 1974.

MAINGUENEAU, D. Novas tendências em Análise do Discurso. 3. ed. Tradução de Freda Indursky. Revisão da tradução de Solange Maria Ledda Gallo, Maria da Glória de Deus Vieira de Moraes. São Paulo: Pontes, 1997.

MAINGUENEAU, D. Análise de textos de comunicação. 6. ed. Tradução de Cecília P. de Souza-e-Silva, Décio Rocha. São Paulo: Cortez, 2011.

ORLANDI, E. P. Discurso e leitura. São Paulo: Cortez, 1993.

ORLANDI, E. P. Interpretação; autoria, leitura e efeitos do trabalho simbólico. Petrópolis: Vozes, 1996.

PAULINO, G.; WALTY, I.; CURY, M. Z. Intertextualidades: teoria e prática. 2. ed. Belo Horizonte: Lê, 1997.

PHIDDIAN, R. Are parody and deconstruction secretly the same thing? Journal of Theory \& Interpretation, Philosophical Thoughts, v. 28, n. 4, Oct. 1997.

PIVIANI, J. Introdução ao cômico. Letras \& Comunicação, Caxias do Sul, a. 1 , n. 2 , jun. 1983.

SANT'ANNA, A. R. Paródia, paráfrase \& Cia. 5. ed. São Paulo: Ática, 1995. 